BACKGROUND: Calprotectin is a calcium-binding and zinc-binding protein complex that is abundant in the cytosol of neutrophils. This factor is composed of 8 and $14 \mathrm{kDa}$ subunits, which have also been termed migration inhibitory factor-related proteins MRP8 and MRP14. We previously reported that rat calprotectin purified from inflammatory neutrophils induces apoptosis of various tumor cells or normal fibroblasts in a zinc-reversible manner.

Aim: The present study was undertaken to elucidate which subunit is responsible for the apoptosisinducing activity, and to explore the mechanism of zinc-reversible apoptosis induction.

Metbods : The apoptosis-inducing activity of recombinant human MRP8 (rhMRP8) and recombinant human MRP14 (rhMRP14) was examined against EL-4 lymphoma cells in vitro. To determine whether zinc deprivation by calprotectin was essential for the cytotoxicity, the activity of calprotectin was tested under conditions where physical contact between the factor and the cells was precluded by a low molecular weight cut-off dialysis membrane.

Results: The cytotoxicity of rhMRP14 against EL-4 cells was first detected at $10 \mu M$ in a standard medium, whereas rhMRP8 caused only marginal cytotoxicity at $40 \mu \mathrm{M}$. A mixture of both proteins showed higher specific activity (onset of cytotoxicity at $5 \mu \mathrm{M}$ ). When the cells were cultured in divalent cation-depleted medium, each dose-response curve was shifted to about a four-fold lower concentration range. Calprotectin was found to induce cell death even when the complex and the target cells were separated by dialysis membrane. A membrane-impermeable zinc chelator, diethylenetriamine pentaacetic acid (DTPA), also induced target cell apoptosis in a similar time-course as calprotectin. Moreover, the activities of calprotectin and DTPA were completely inhibited by the presence of zinc ions.

Conclusion: These data indicate that calprotectin has higher specific activity to induce apoptosis than the individual subunits, and that the mechanism is exclusion of zinc from target cells.

Key words: S100A8/S100A9, Cytotoxicity, Neutrophils

\section{Implication of extracellular zinc exclusion by recombinant human calprotectin (MRP8 and MRP14) from target cells in its apoptosis-inducing activity}

\author{
Satoru Yui ${ }^{1, C A}$, Yuichi Nakatani ${ }^{1}$, \\ Michael J. Hunter ${ }^{2,3}$ Walter J. Chazin ${ }^{2}$ and \\ Masatoshi Yamazaki ${ }^{1}$
}

${ }^{1}$ Faculty of Pharmaceutical Sciences, Teikyo University, 1091-1 Sagamiko, Tsukui-gun, Kanagawa 199-0195, Japan; ²Department of Biochemistry, Department of Physics and Center for Structural Biology, Vanderbilt University, Nashville, TN 37232-0146, USA ${ }^{3}$ Present address: Corvas, Inc., San Diego, CA, USA.

\footnotetext{
${ }^{\mathrm{CA}}$ Corresponding author

Tel: +81426853736

Fax: +81426852574

E-mail: sat-yui@pharm.teikyo-u.ac.jp
}

\section{Introduction}

Neutrophils are known to be inflammatory cells that secrete many protein factors including enzymes, antibacterial proteins, and cytokines. They play a role in controlling inflammation, in addition to killing microorganisms. ${ }^{1,2}$ While searching for the regulatory activity within the neutrophils, we found that rat neutrophils contain a factor having cytostatic activity against lymphocytes. ${ }^{3}$ This factor is calprotectin. ${ }^{4}$ We subsequently reported that rat calprotectin has apoptosis-inducing activity against various tumor cells ${ }^{5}$ and normal cell types including fibroblasts. ${ }^{6}$ The apoptosis-inducing activity was abrogated by zinc ions, but not by calcium ions. ${ }^{4-6}$
Calprotectin is a calcium-binding and zinc-binding protein complex composed of 8 and $14 \mathrm{kDa}$ proteins. $^{7}$ These proteins, which belong to the $\mathrm{S100}$ protein family, ${ }^{8}$ have also been termed migration inhibitory factor-related proteins (MRP)-8 and MRP 14, ${ }^{9}$ calgranulin $\mathrm{A}$ and $\mathrm{B},{ }^{10}$ or S100A8 and S100A9. ${ }^{11}$ Neutrophils are believed to be a predominant producer of calprotectin since they contain a high amount of the proteins in cytosol. ${ }^{12}$ The concentration of calprotectin in extracellular fluids increases under various inflammatory conditions, ${ }^{13-17}$ suggesting that this factor has important functions influencing inflammatory processes. The concentration in normal human serum was reportedly less than $1 \mu \mathrm{g} / \mathrm{ml}$, but the titers increase in many 
pathological conditions including cystic fibrosis, rheumatoid arthritis, or Crohn's disease (reviewed elsewhere ${ }^{17}$ ). Much intense increase in calprotectin concentration has been observed in body fluids of local inflammatory sites than in blood: the concentration in synovial fluid of patients with rheumatoid arthritis was reported to increase sometimes to more than $100 \mu \mathrm{g} / \mathrm{ml}^{13,15}$ Very high concentrations $(1-20 \mathrm{mg} / \mathrm{ml})$ of calprotectin reportedly existed in abscess fluid from human abdominal abscesses. ${ }^{16}$

Evidence unraveling the extracellular functions of calprotectin or its subunit have been accumulating recently. For example, antimicrobial activity ${ }^{18-21}$ and regulatory activities towards migration or adherence of inflammatory cells have been proposed. ${ }^{22,23}$ The exact physiological roles of this protein complex, however, await further investigation.

Our findings concerning the growth-inhibiting and cell-death-inducing activity suggest that calprotectin plays a regulatory role in inflammatory processes through its effect on the survival and/or growth of cells involved in the inflammation. It is also suggested that if a high concentration of calprotectin is present in the body fluid at locally inflamed sites, this might cause a delay in tissue repair and have a deleterious effect on the inflamed tissues. Therefore, discovery of the mechanism of the apoptosis induction by calprotectin might be important in controlling of inflammation. The present study was undertaken to determine whether human calprotectin has apoptosis-inducing activity, as observed previously for the rat protein complexes. The activities of the MRP8 and MRP14 alone were compared with that of the mixture using recombinant human MRP8 (rhMRP8) or recombinant human MRP14 (rhMRP14). We also explored the mechanism of induction of zinc-reversible apoptosis. The results show that an equimolar mixture of rhMRP8 and rhMRP14 has higher specific activity than the individual proteins, and suggests that apoptosis is induced by exclusion of extracellular zinc ions by calprotectin from target cells.

\section{Materials and methods}

\section{Reagents}

Diethylenetriamine pentaacetic acid (DTPA) and $N, N, N^{\prime}, N^{\prime}$-tetrakis-(2-pyridylmethyl)ethylenediamine (TPEN) were purchased from Sigma (St Louis, MO, USA). $\mathrm{ZnSO}_{4} \cdot 7 \mathrm{H}_{2} \mathrm{O}$ and other chemicals were from Wako Pure Chemical Industries (Osaka, Japan).

\section{Recombinant human MRP8 and recombinant human MRP14}

Recombinant human calprotectin (rhMRP8 and rhMRP14) was prepared as described elsewhere, ${ }^{24}$ with some modifications. Briefly, competent Escherichia coli strain BL21(DE3) cells (Novagen, Madison,
WI, USA) were transformed by pET1120-MRP8wt or pET1120MRP14wt vectors. The transformed cells were grown in $(2 \times$ YT) media supplemented with $100 \mu \mathrm{g} / \mathrm{ml}$ of ampicillin for $24 \mathrm{~h}$, and the cells produced the proteins as inclusion bodies. The harvested cells were solubilized with B-PER ${ }^{\mathrm{TM}}$ Bacterial Protein Extraction Reagent (Pierce, Rockford, IL, USA). The inclusion bodies were solubilized with Inclusion Body Solubilization Reagent (Pierce), and the proteins were refolded according to the manufacturer's protocol. The proteins were purified by reverse-phase column chromatography (Resource ${ }^{\mathrm{TM}}$ RPC; Amersham Pharmacia, Buckinghamshire, England) furnished in a BioLogic HR system (Bio-Rad), followed by UNO-Q anion exchange chromatography (Bio-Rad, Hercules, CA, USA). The buffer systems used were the same as those described previously. ${ }^{24}$

\section{Cell lines}

Mouse EL- 4 thymoma cells, human MOLT- 4 leukemia and MCF-7 mammary carcinoma lines were maintained in RPMI 1640 medium supplemented with 5\% fetal calf serum (FCS). MM46, a transplantable ascites tumor from a spontaneous mammary carcinoma in a $\mathrm{C} 3 \mathrm{H} / \mathrm{He}$ mouse, was passaged weekly in the peritoneal cavity of male $\mathrm{C} 3 \mathrm{H} / \mathrm{He}$ mice (Japan SLC Inc., Shizuoka, Japan).

\section{3-(4,5-Dimetyl-2-thiazolyl)-2,5-diphenyl-2 $\mathrm{H}$ - tetrazolium bromide assay}

To evaluate the target cell death, the 3-(4,5-dimethyl2-thiazolyl)-2,5-diphenyl-2 $\mathrm{H}$-tetrazolium bromide (MTT) assay was used. ${ }^{25}$ EL- 4 cells or MM 46 cells $(1 \times$ $10^{4}$ cells/well) were cultured in 96-well microtest plates (Iwaki, Chiba, Japan) with $200 \mu 1$ of RPMI 1640 medium (100 U of penicillin, $60 \mu \mathrm{g}$ of kanamycin $/ \mathrm{ml}$, supplemented with 5\% FCS). The cultures were added with test samples, and cells were incubated at $37^{\circ} \mathrm{C}$ in a humidified atmosphere of $5 \% \mathrm{CO}_{2}$ in air. After the indicated periods, $25 \mu \mathrm{l}$ of MTT $(5 \mathrm{mg} / \mathrm{ml})$ was added to the cultures, and plates were incubated for an additional $3 \mathrm{~h}$. Then, $150 \mu \mathrm{l}$ of the supernatants was discarded, $100 \mu \mathrm{l}$ of acidified isopropanol $(0.04 \mathrm{~N} \mathrm{HCl}$ in 2-propanol) was added to each well and the optical density $(595 \mathrm{~nm})$ was measured with a microplate reader (Multiscan MS-UV; Labsystems, Basingstoke, UK).

\section{Divalent cation (other than $\mathrm{Ca}^{2+}$ and $\mathrm{Mg}^{2+}$ )-depleted medium}

To prepare divalent cation-depleted medium, $100 \mathrm{ml}$ of RPMI-1640 medium containing 5\% FCS that had been extensively dialyzed against PBS was applied to a Chelex 100 column (Bio-Rad; $1.0 \times 20 \mathrm{~cm}$ ). Then, $500 \mu \mathrm{M} \mathrm{CaCl} 2$ and $400 \mu \mathrm{M} \mathrm{MgCl}_{2}$ were added to supplement calcium and magnesium. 


\section{Double-chamber culture}

The requirement of direct contact between rhMRP8/ rhMRP14 complex and EL- 4 cells to exert cytotoxic effects was examined by the double-chamber culture system. For this, plastic cylinders $(15 \mathrm{~mm}$ in height, $10 \mathrm{~mm}$ in inner diameter) were used with the edge on one side sealed with dialysis membrane (3500 cut-off; Spectrum Medical Ind., Los Angeles, CA, USA) as inner chambers. These inner chambers were set in the wells of 24-well culture plates (Iwaki) at a location approximately $3 \mathrm{~mm}$ distant from the dialysis membrane in the inner chamber and the bottom of the wells of the 24-well plates (the outer chambers). The total culture volumes of the inner and outer chambers were $425 \mu 1$ and $1000 \mu l$, respectively. Divalent cation-depleted medium without or with the rhMRP8/rhMRP14 complex $(7 \mu \mathrm{M})$ was added to the chambers as indicated, and the doublechamber system was kept at $4^{\circ} \mathrm{C}$ for 3 days. Thereafter, EL- 4 cells $\left(2.5 \times 10^{4}\right.$ cells and $5 \times 10^{4}$ cells $)$ were added to the inner and outer chambers, respectively, and the cells were cultured at $37^{\circ} \mathrm{C}$. After $48 \mathrm{~h}$ of culture, $200 \mu \mathrm{l}$ aliquots of suspended culture was transferred to 96-well plates to measure the capacity of MTT reduction of EL- 4 cells in each chamber, using the MTT assay already described.

\section{DNA fragmentation}

EL-4 cells were cultured in 12-well plates (Corning, Corning, NY, USA) at $3 \times 10^{6}$ cells with test samples for the indicated periods to analyze DNA fragmentation. After the cells were harvested and washed once with PBS, $1.5 \mu \mathrm{g}$ DNA extracted with a Genomic DNA Purification Kit (Promega, Madison, WI, USA) was separated by electrophoresis on $1.5 \%$ agarose gel in TAE buffer ( $40 \mathrm{mM}$ Tris- $\mathrm{HCl}, 19 \mathrm{mM}$ acetic acid, and $1 \mathrm{mM}$ ethylenediamine tetraacetic acid) containing $0.5 \mu \mathrm{g} / \mathrm{ml}$ of ethidium bromide.

\section{Results}

\section{Cell-death-inducing activity of human recombinant calprotectin chains}

We previously reported that calprotectin (MRP8/ MRP14 complex) derived from rat inflammatory neutrophils induces apoptosis of various tumor cells $^{4,5,25}$ and normal fibroblasts, ${ }^{6}$ and that the apoptosis-inducing activity is abrogated by the presence of zinc. ${ }^{4-6}$ To determine whether human calprotectin shows this cytotoxic activity, and which subunit of the protein complex is responsible for the activity, we compared the cytotoxicity to EL-4 cells of rhMRP8, rhMRP14 and a mixture of the two, using the MTT assay.
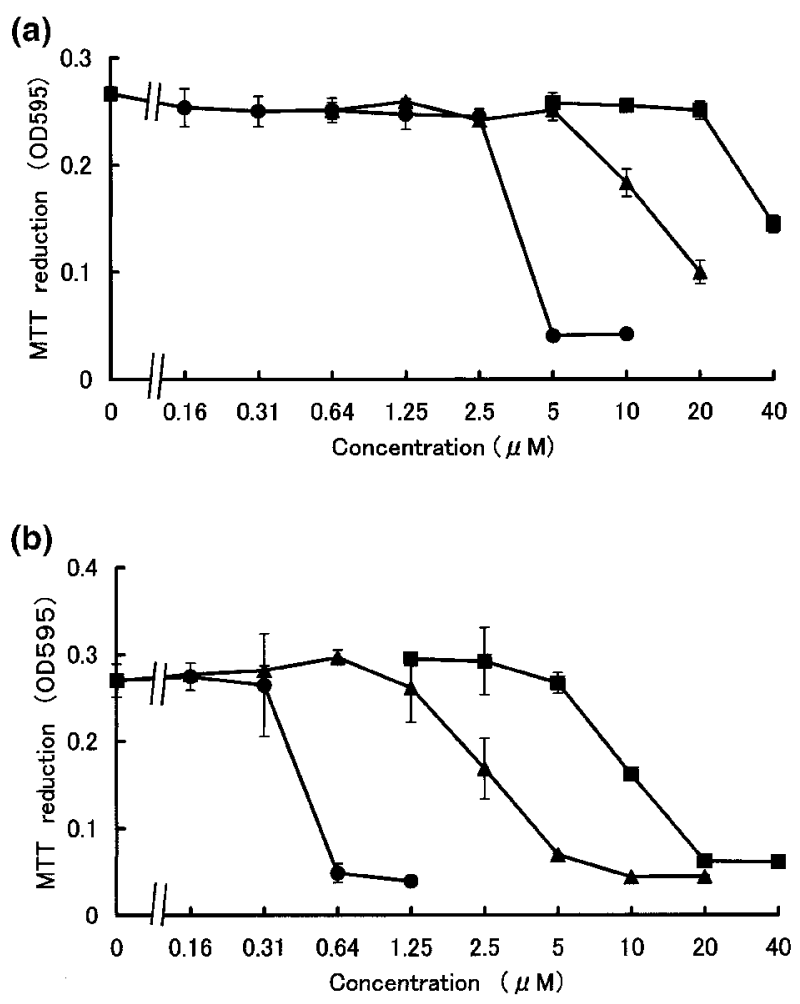

FIG. 1. Effect of rhMRP8, rhMRP14 or MRP8/MRP14 complex on the number of EL-4 cells. Cells were cultured with the indicated concentrations of $(\mathbf{\square})$ rhMRP8, ( $\mathbf{\Delta})$ rhMRP14, or (-) an equimolar mixture in (a) standard RPMI-1640 medium or (b) in divalent-cation-depleted medium for $40 \mathrm{~h}$. Cell numbers were estimated by MTT reduction. Bars represent upper and lower values of duplicate estimations. When bars are not shown, they are smaller than the size of the symbols.

Figure 1a shows that rhMRP14 had more potent activity than rhMRP8. rhMRP14 inhibited MTT reduction in EL- 4 cells, with an onset at a concentration of $10 \mu \mathrm{M}$ and marked inhibition at $20 \mu \mathrm{M}$, whereas rhMRP8 showed no inhibition of MTT reduction until a concentration of $40 \mu \mathrm{M}$. On the contrary, equimolar solutions of MRP8 and MRP14 showed even more potent activity with almost complete inhibition at $5 \mu \mathrm{M}$. It was observed microscopically that the inhibition of MTT reduction paralleled the emergence of apoptotic bodies and apoptotic cells having an apoptotic appearance, such as condensation or segregation of nuclei.

We previously reported that the effects of calprotectin were shifted to lower concentration ranges in media depleted of divalent cations other than $\mathrm{Ca}^{2+}$ and $\mathrm{Mg}^{2+}{ }^{6}$ We next examined whether the specific activities of rhMRP8, rhMRP14 or their mixture were also augmented in divalent cation-depleted medium. Figure $1 \mathrm{~b}$ shows that, in fact, the dose-response curves are shifted to about a four-fold lower concentration. A similar observation was made in examining the effects of calprotectin on MM46 mammary carcinoma cells (data not shown). 


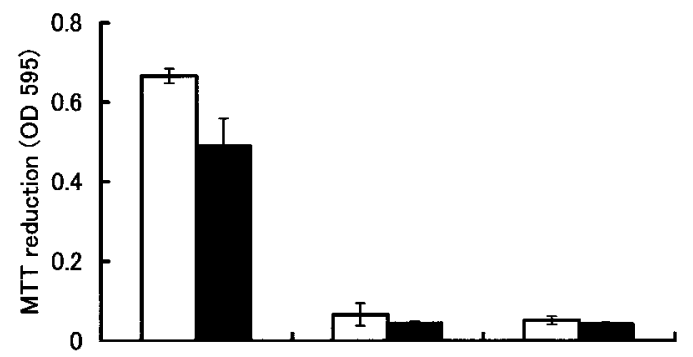

\begin{tabular}{|l|c|c|c|}
\hline Inner Chamber & - & - & + \\
\hline Outer Chamber & - & + & + \\
\hline
\end{tabular}

FIG. 2. Test of the requirement for direct contact between rhMRP8/rhMRP14 and EL-4 cells to exert a cytotoxic effect. Divalent-cation-depleted medium without or with rhMRP8/ rhMRP14 complex was added to the inner and outer chambers of a double-chamber culture system, in which the two chambers were separated by dialysis membrane $(3500$ cut-off) as described in Materials and methods. After being stored at $4^{\circ} \mathrm{C}$ for 3 days, EL- 4 cells were added to the inner and outer chambers as indicated. After culturing for $48 \mathrm{~h}$, MTT-reducing activity of EL-4 cells in the inner chamber (white bars) and the outer chamber (black bars) were measured. Bars represent standard deviations of triplicate estimations.

\section{Lack of required calprotectin binding to the} target cells in cell death induction

Sohnle and co-workers suggested that the candidastatic activity of calprotectin is caused by exclusion of zinc from medium. ${ }^{26}$ Moreover, there is accumulating evidence that the exclusion of intracellular zinc by cell-membrane-permeable zinc chelators such as TPEN induces apoptosis of target cells. ${ }^{27-30} \mathrm{We}$ were therefore motivated to investigate whether the exclusion of extracellular zinc by calprotectin causes target cell apoptosis. Thus, although no reduction in the number of EL- 4 cells grown is found in divalent cationdepleted medium (Fig. 1), the presence of even a trace amount of zinc supports cell growth.

If extracellular zinc chelation is the mechanism of apoptosis induction, it is possible that direct interaction of calprotectin with cells is not required. To test this hypothesis, we prepared a double-chamber culture in which inner and outer chambers were separated by a dialysis membrane (3500 cut-off), thereby precluding direct interactions between calprotectin and the EL- 4 cells. To pre-equilibrate zinc concentrations before the addition of the cells, zincdeprived medium with or without calprotectin was added in both chambers and allowed to stand at $4^{\circ} \mathrm{C}$ for 3 days to equilibrate zinc concentrations. As shown in Figure 2, pretreatment of inner and outer chambers with calprotectin resulted in the inhibition of MTT reduction of EL- 4 cells in the both chambers. On the contrary, when only the outer chambers were pretreated, the inhibition was again observed not only in the outer chambers, but also in (a)

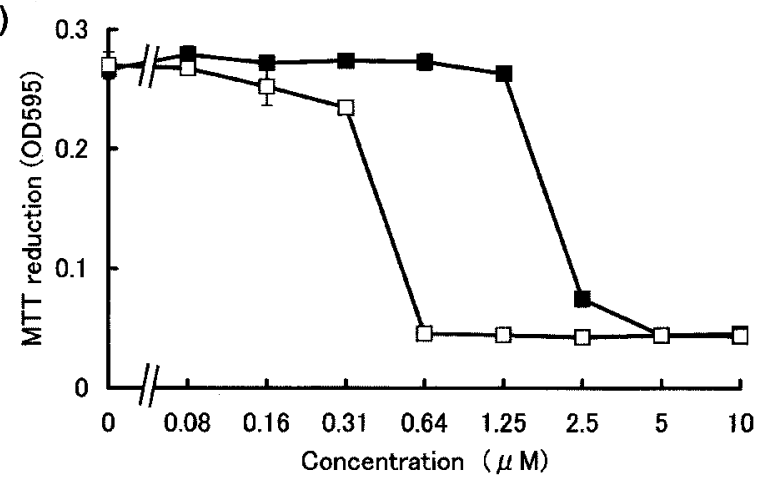

(b)

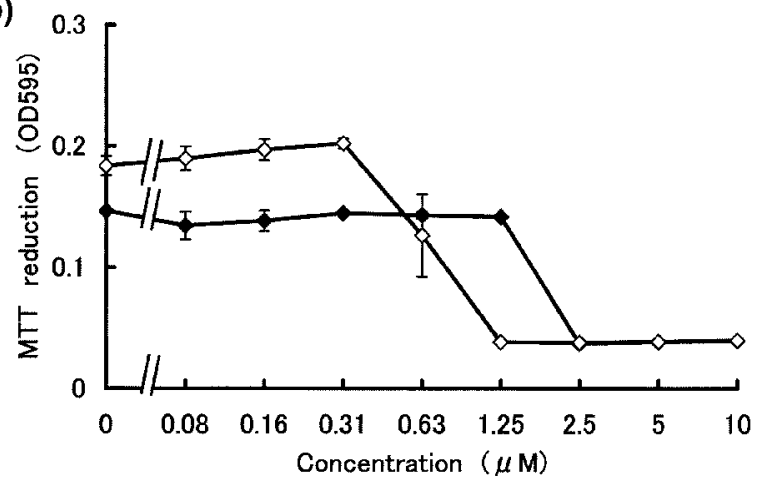

FIG. 3. EL-4 cell cytotoxicity of the cell-membrane-impermeable Zn-chelator DTPA or the cell-membrane-permeable Znchelator TPEN. The cells were cultured with (a) DTPA or (b) TPEN in standard medium (closed symbols) or in divalentcation-depleted medium (open symbols). MTT assays were preformed after culturing for (a) $48 \mathrm{~h}$ or (b) $24 \mathrm{~h}$. Bars represent standard deviations of triplicate measurements. When bars are not shown, they are smaller than the size of the symbols.

the inner chambers, showing that direct contact between calprotectin and the target cells was not necessary for induction of cell death. It was confirmed that calprotectin was not permeable to the opposite chambers: when only the outer chambers were pretreated with calprotectin as already described, the subunit proteins in the supernatants from the inner chambers were not detected by sodium dodecyl sulfate-polyacrylamide gel electrophoresis with silver staining, while the proteins in $0.64 \mu \mathrm{M}$ calprotectin solution, which was the minimal concentration for apoptosis induction in divalent-cationdepleted medium, were clearly detectable (data not shown).

\section{Apoptosis-inducing effects of zinc chelators}

To obtain further evidence that exclusion of extracellular zinc induces cell death, we next studied the toxicity of zinc chelators. As shown in Figure 3a, DTPA (which is a cell-membrane-impermeable chelator) causes almost complete loss of MTT 


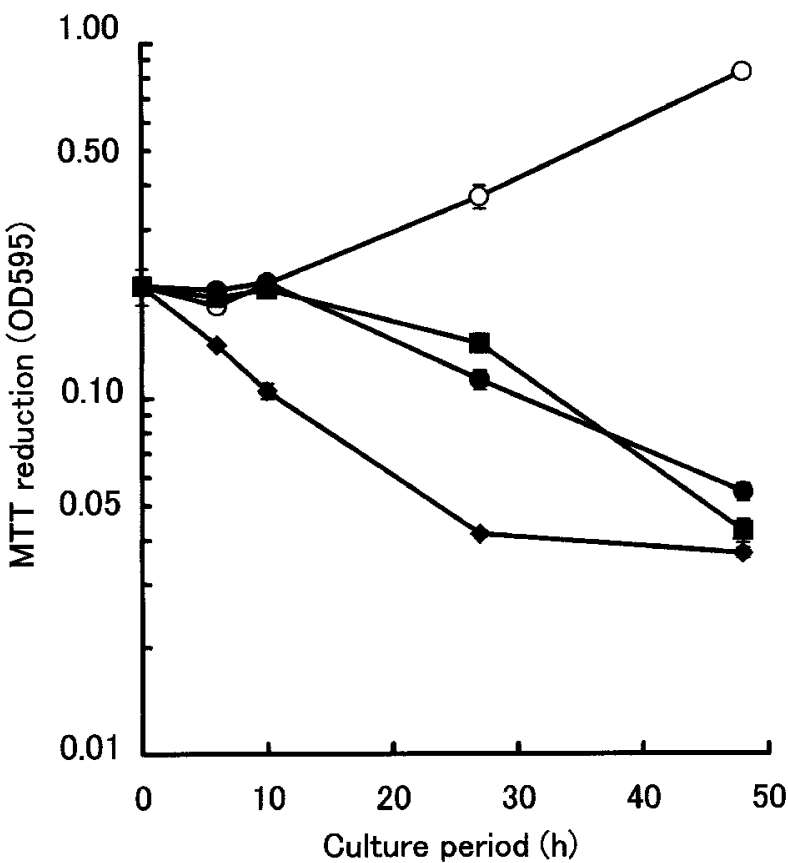

FIG. 4. Time-courses of the cell-death-inducing activity of rhMRP8/rhMRP14 complex, DTPA or TPEN. EL-4 cells were cultured $(\bigcirc)$ without, or $(\bullet)$ with rhMRP8/rhMRP14 complex $(5 \mu \mathrm{M})$, ( $\square)$ with DTPA $(10 \mu \mathrm{M})$ or $(\diamond)$ with TPEN $(5 \mu \mathrm{M})$ in standard medium. MTT assays were performed at the timepoints indicated as described in Materials and methods. Bars represent standard deviations of triplicate measurements.

reduction in EL- 4 cells at a concentration of $2.5 \mu \mathrm{M}$ in normal medium and at $0.63 \mu \mathrm{M}$ in divalentcation-depleted medium. Like calprotectin, the cytotoxic activity of DTPA was more potent in divalentcation-depleted medium than in normal medium. The membrane-permeable chelator, TPEN, which was earlier reported to have apoptosis-inducing activity, ${ }^{27-30}$ also completely suppressed MTT reduction at $2.5 \mu \mathrm{M}$ in normal medium and at $1.25 \mu \mathrm{M}$ in divalent-cation-depleted medium (Fig. 3b). Calprotectin and DTPA also induced a decrease in MTT-reducing activity of human cell lines, namely MOLT-4 leukemia cells and MCF-7 mammary carcinoma cells, in quite similar concentration ranges as the case of EL- 4 cells, respectively (data not shown).

Figure 4 shows a kinetic study of changes in MTT reduction of EL- 4 cells cultured with calprotectin or zinc chelators. Calprotectin induced a decrease of about half in the MTT reduction after $27 \mathrm{~h}$ and a complete loss of activity at $48 \mathrm{~h}$ of incubation. A membrane-impermeable DTPA suppressed MTT reduction with similar kinetics as calprotectin, while membrane-permeable TPEN caused the suppression with more rapid kinetics.

To ascertain whether DTPA induces apoptosis of EL- 4 cells, we analyzed the DNA profile of EL- 4 cells cultured with DTPA since DNA fragmentation is a hallmark of apoptosis. As shown in Figure 5, in

\section{Marker Control CHX TPEN MRP8/14 DTPA}

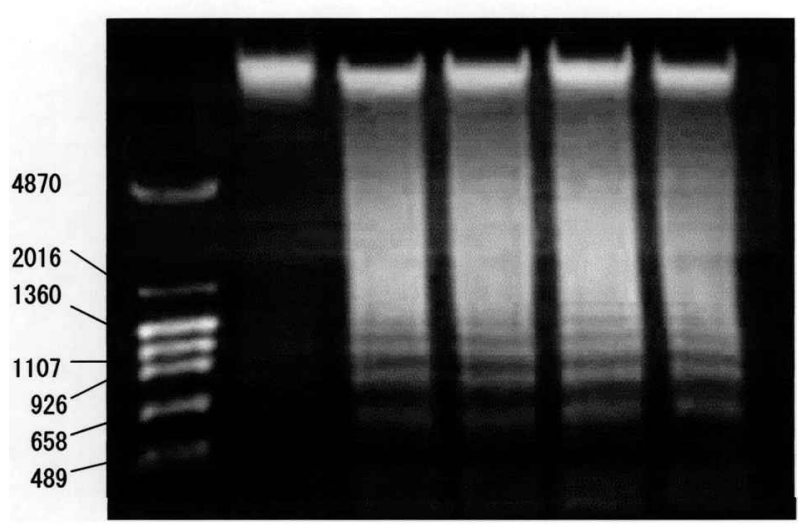

FIG. 5. Agarose gel electrophoresis of DNA extracted from EL-4 cells. Cells were cultured in standard medium without or with rhMRP8/rhMRP14 complex $(5 \mu \mathrm{M})$ on DTPA $(20 \mu \mathrm{M})$ for $24 \mathrm{~h}$, or with TPEN $(10 \mu \mathrm{M})$ or cycloheximide (CHX) $(200 \mu \mathrm{g} / \mathrm{ml})$ for $6 \mathrm{~h}$. DNA was extracted and electrophoresed as described in Materials and methods.

addition to TPEN and cycloheximide used as positive controls, recombinant human calprotectin and DTPA both induced ladder-type DNA fragmentation, and consequently apoptosis.

Evidence of whether zinc chelation is essential in the cytotoxic mechanism of calprotectin and DTPA was sought by examining the effect of the addition of zinc sulfate on the cytotoxic activities. As shown in Figure 6, the cytotoxicity of DTPA and calprotectin as well as TPEN was completely abrogated by the

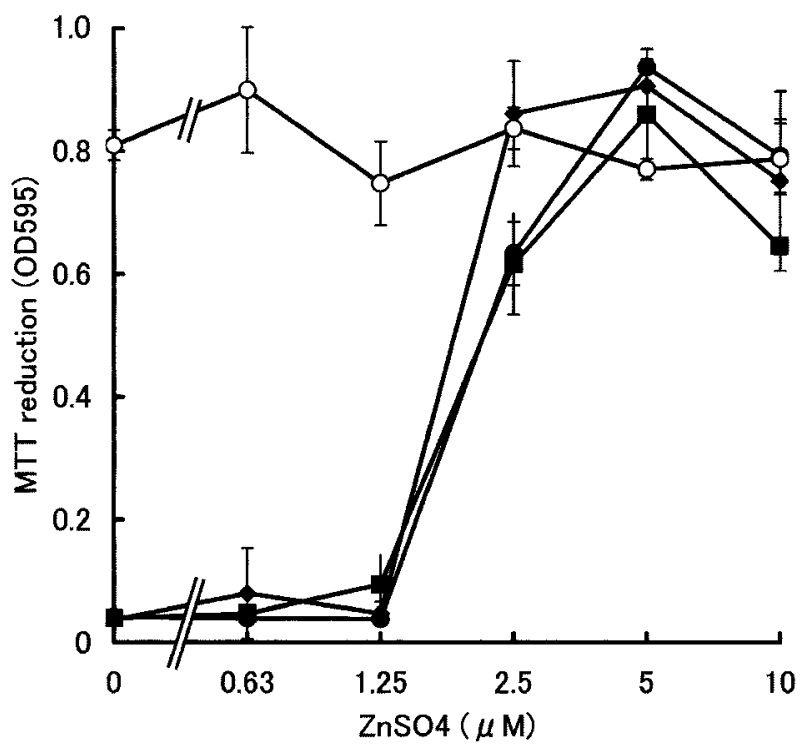

FIG. 6. Inhibitory effect of $\mathrm{ZnSO}_{4}$ on apoptosis-inducing activity of rhMRP8/rhMRP14 complex, DTPA, or TPEN. EL-4 cells were cultured in divalent-cation-depleted medium $(O)$ without, or $(\bullet)$ with rhMRP8/rhMRP14 complex $(2.5 \mu \mathrm{M})$, with (घ) DTPA $(2.5 \mu \mathrm{M})$ or $(\downarrow)$ with TPEN $(2.5 \mu \mathrm{M})$ for $48 \mathrm{~h}$ in the absence or presence of the indicated concentrations of $\mathrm{ZnSO}_{4}$. 
presence of zinc sulfate, suggesting that zinc chelation is truly implicated in apoptosis induction by DTPA and calprotectin.

\section{Discussion}

In the present report we have examined the apoptosis-inducing activities of the calprotectin heterodimer and its constituent subunits using recombinant human proteins. An equimolar mixture of rhMRP8 and rhMRP14 was found to have higher specific activity than either subunit alone. The effective concentrations of rhMRP8/rhMRP14 activities are similar to those previously reported for rat calprotectin. ${ }^{5}$ Therefore, it is concluded that apoptosisinducing activity is not unique to rat calprotectin.

There are several observations supporting a specific mechanism for the induction of apoptosis by calprotectin that involves the exclusion of extracellular zinc. First, the cell-death-inducing activity of rhMRP8/rhMRP14 (Fig. 6), as well as rat calprotectin, ${ }^{4-6}$ was completely inhibited by the co-presence of zinc. Second, corresponding dose-response curves were shifted to lower concentration ranges in divalent-cation-depleted medium (Fig. 1). ${ }^{6}$ Third, direct physical contact between calprotectin and tumor cells was not required to exert cytotoxicity. Finally, the membrane-impermeable zinc chelator DTPA decreased the MTT-reducing activity of EL-4 cells in a time-course similar to that of calprotectin, whereas membrane-permeable zinc chelator TPEN exerted cytotoxicity more rapidly. It was previously reported that rhMRP8 and rhMRP14 form a noncovalently associated heterodimeric complex with high preference over homodimers. ${ }^{24,31}$ The mixture of MRP8 and MRP14 has higher specific activity than either protein individually, and these proteins appear to acquire higher zinc binding activity in the heterodimeric state. This hypothesis is supported by the $\mathrm{X}$-ray crystal structure of $\mathrm{Zn}^{2+}$-bound S100A $7^{32}$ and by molecular modeling of the $\mathrm{Zn}^{2+}$-binding sites in S100A6 and S100A2. ${ }^{33,34}$

The results presented herein suggest that direct interaction is not required for the cytotoxic activity exerted by calprotectin on target cells. However, human leukemia cell lines ${ }^{22,35}$ and endothelial cells ${ }^{23}$ reportedly have binding sites for MRP8 and MRP14, suggesting that some cell types have receptor(s) for calprotectin. It is conceivable that membrane-bound calprotectin is more effective in inducing apoptosis than the freely soluble protein. One plausible explanation for this would be the effective localization of calprotectin to cells requiring its $\mathrm{Zn}$-chelating activity.

Antifungal activity was reported to be an extracellular function of calprotectin. ${ }^{18-21}$ Sohnle and coworkers reported that calprotectin exerted a candidastatic effect by eliminating zinc in a medium that is essential for Candida growth. ${ }^{26}$ Recent studies of the antimicrobial activities of calprotectin using rhMRP8 and rhMRP14 examined Cys $\rightarrow$ Ser mutations, which avoid unwanted formation of disulfides. ${ }^{21}$ These workers found that neither MRP8 nor MRP14 showed antimicrobial activity by itself, whereas equimolar concentrations of the two proteins potently inhibited growth. Our studies of the apoptosis-inducing activities of recombinant wild-type proteins revealed that MRP14 and MRP8 alone were able to cause target cell death, although their specific activities were lower than that of the mixture. This discrepancy prompted us to examine the suppression of the growth of Candida albicans by the wild-type proteins. Interestingly, we found that the isolated rhMRP14 and rhMRP8 (as well as the mixture) exhibited doseresponse curves quite similar to those of their cytotoxicity against EL- 4 cells (unpublished observation), including the enhancement of activity in divalent-cation-depleted media. The apparent difference between wild-type and mutated proteins is surprising. The most probable explanation is that the single cysteine residues in MRP14 and MRP8 play key roles in the binding of $\mathrm{Zn}^{2+}$ ions. Substitution of these residues by serine is anticipated to significantly reduce $\mathrm{Zn}^{2+}$ affinity, although a corresponding effect on the MRP14/MRP8 heterodimer would be anticipated. Clearly, further studies are required to establish the cause of these apparent discrepancies.

Recently, evidence has been accumulating that implicates zinc deficiency in induction of apoptosis. Zinc ions are observed to inhibit apoptotic nuclea$\operatorname{ses}^{36}$ and caspase activation, ${ }^{37}$ and chelation of intracellular zinc from cells induces apoptosis. ${ }^{27-30}$ Martin et al. reported that human cell lines, Raji and HL-60, undergo apoptosis in zinc-deficient media. ${ }^{38}$ However, the effect of extracellular zinc exclusion on induction of apoptosis has not been fully elucidated. To our knowledge, calprotectin is the first example that an endogenous factor present in body fluids induces apoptosis by zinc exclusion from target cells. Future studies will examine how extracellular zinc chelation by calprotectin or DTPA affects intracellular zinc concentration.

An intense increase in calprotectin concentration has been observed in body fluids at local sites of inflammation, ${ }^{17}$ with an extremely high amount of calprotectin $(1-20 \mathrm{mg} / \mathrm{ml}$, i.e. $45-900 \mu \mathrm{M}$ as a heterodimeric complex) in abscess fluids. ${ }^{16}$ On the contrary, zinc concentrations in serum of healthy human subjects is about $15 \mu \mathrm{M}$ on average, ${ }^{39}$ and more than one-half of serum zinc binds with albumin or amino acids and is thought to be exchangeable with other ligands. ${ }^{40}$ In areas where blood flow is limited in the inflammatory sites, zinc deficiency may be induced locally by calprotectin and may lead to apoptosis. This high abundance of calprotectin might be injurious to the cells in inflamed tissues if there is an insufficient 
amount of zinc present. Calprotectin concentrations in local inflammatory sites such as abscesses, in which neutrophils extensively accumulate, may surpass the inhibitory effect of zinc or other inhibitory metals. ${ }^{6}$ This is supported by the observation reported by Sohnle et al. that the supernatant fluids of abscess showed antifungal activity and that the activity was completely reversed by an addition of zinc. ${ }^{41}$ The findings in the present paper may help to make a remedy for inflammation. For instance, the possibility can be raised that zinc supplement may suppress tissue destruction in local inflammatory sites, although in vivo activity of calprotectin awaits further research. Also, the mechanism underlying apoptosis induction by calprotectin may be related to the pathology of zinc deficiency.

The apoptosis-inducing activity of calprotectin by zinc chelation might also function in intracellular environments. Calprotectin is expressed abundantly in the cytosol of neutrophils on differentiation of the cell lineage, and the concentration of cytosolic calprotectin in neutrophils has been estimated at $3 \mathrm{mM}^{12}$ Future research must examine whether calprotectin is an endogenous factor of neutrophils that contributes to, or perhaps even determines, the brief life span of this cell type.

ACKNOWLEDGMENTS. The authors are grateful to Mina Fukushima for technical assistance. Research in the Chazin laboratory was supported by an operating grant from the National Institutes of Health (R01 GM62112) and a fellowship to M.J.H. from the National Arthritis Foundation.

\section{References}

1. Lloid AF, Oppenheim JJ. Poly's lament: the neglected role of the polymorphonuclear neutrophil in the afferent limb of the immune response. Immunol Today 1992; 13: 169-172.

2. Cassatella MA. The production of cytokines by polymorphonuclear neutrophils. Immunol Today 1995; 16: 21-26.

3. Yui S, Yang D, Mikami M, Yamazaki M. Characterization of cell growth inhibitory factor in inflammatory peritoneal exudate cells of rats. Microbiol Immunol 1993; 37: 961-969.

4. Yui S, Mikami M, Yamazaki M. Purification and characterization of the cytotoxic factor in rat peritoneal exudate cells: its identification as the calcium binding protein complex, calprotectin. J Leuk Biol 1995; 58 : 307-316.

5. Yui S, Mikami M, Yamazaki M. Induction of apoptotic cell death in mouse lymphoma and human leukemia cell lines by a calcium-binding protein complex, calprotectin, derived from inflammatory peritoneal exudate cells. J Leuk Biol 1995; 58: 650-658.

6. Yui S, Mikami M, Yamazaki M. Growth-inhibitory and apoptosis-inducing activities of calprotectin derived from inflammatory exudate cells on normal fibroblasts: regulation by metal ions. J Leuk Biol 1997; 61: 50-57.

7. Dale I, Fagerhol MK, Naesgaard I. Purification and partial characterization of a highly immunogenic human leukocyte protein, the L1 antigen. Eur J Biochem 1983; 134: 1-6.

8. Schäfer BW, Heinzmann CW. The $\$ 100$ family of EF-hand calcium-binding proteins: functions and pathology. Trends Biochem Sci 1996; 21 $134-140$.

9. Odink K, Cerletti N, Brüggen J, Clerc R, Tarcsey L, Zwadlo G, Gerhards G Schlegel R, Sorg C. Two calcium-binding proteins in infiltrate macrophages of rheumatoid arthritis. Nature 1987; 330: 80-82.

10. Wilkinson MM, BusuttiA, Hayward C, Brock DJH, Dorin JR, van Heynigen V. Expression pattern of two related cystic fibrosis-associated calcium binding proteins in normal and abnormal tissues. J Cell Sci 1988; 91: 221-230.

11. Schäfer BW, Wicky R, Engelkamp MK, Mattei MG, Heizmann CW Isolation of a YAC clone covering a cluster of nine S100 genes on human chromosome 1Q21: rationale for a new nomenclature of the $\$ 100$ calcium-binding protein family. Genomics 1995; 25: 638-643.
12. Hessian P, Edgeworth J, Hogg N. MRP-8 and MRP-14, two abundant Ca ${ }^{2+}$ binding proteins of neutrophils and monocytes. J Leuk Biol 1993; 53 : 197-204.

13. Berntzen HB, Ölmez Ü, Fagerhol MK, Munthe E. The leukocyte protein L1 in plasma and synovial fluid from patients with rheumatoid arthritis and osteoarthritis. Scand J Rbeumatol 1991; 20: 74-82.

14. Brun JG, Cuida M, Jacobson H, Kloster R, Johannesen AC, Hoyeraal HM, Jonsson R. Sjögren's syndrome in inflammatory rheumatic diseases: analysis of the leukocyte protein calprotectin in plasma and saliva. Scand J Rbeumatol 1994; 23: 114-118.

15. Brun JG, Jonsson R, Haga H-J. Measurement of plasma calprotectin as an indicator of arthritis and disease activity in patients with inflammatory rheumatic diseases. J Rbeumatol 1993; 21: 733-738.

16. Clohessy PA, Golden BE. Calprotectin-mediated zinc chelation as a biostatic mechanism in host defense. Scand J Immunol 1995; 42: 551-556.

17. Johne B, Fagerhol MK, Lyberg T, Prydz H, Brandtæg P, Naess-Andresen CF, Dale I. Functional and clinical aspects of the myelomonocyte protein calprotectin. J Clin Pathol Mol Pathol 1997; 50: 113-123.

18. Steinbakk M, Naess-Andresen C-F, Lingaas E, Dale I, Brandtzaeg P, Fagerhol MK. Antimicrobial actions of calcium binding leukocyte L1 protein, calprotectin. Lancet 1990; 336: 763-765.

19. Sohnle PG, Collins-Lech C, Wiessner JH. Antimicrobial activity of an abundant calcium-binding protein in the cytoplasm of human neutrophils. J Infect Dis 1991; 163: 187-192.

20. Murthy ARK, Lehrer RI, Harwig SSL, Miyazaki KT. In vitro candidastatic properties of the human neutrophil calprotectin complex. I Immunol 1993; 151: 6291-6301.

21. Sohnle PG, Hunter MJ, Hahn B, Chazin WJ. Zinc-reversible antimicrobial activity of recombinant calprotectin (Migration inhibitory factor-related proteins 8 and 14). J Infect Dis 2000; 182: 1272-1275.

22. Newton RA, Hogg N. The human S100 protein MRP-14 is a novel activator of the $\beta_{2}$ integrin Mac-1 on neutrophils. J Immunol 1998; 160: 1427-1435.

23. Srikrishna G, Panneerselvam K, Westphal V, Abraham V, Varki A, Freeze HH. Two proteins modulating transendothelial migration of leukocytes recognize novel carboxylated glycans on endothelial cells. $J$ Immunol 2001; 166: 4678-4688.

24. Hunter MJ, Chazin WJ. High level expression and dimer characterization of the S100 EF-hand proteins, migration inhibitory factor-related proteins 8 and 14. J Biol Chem 1998; 273: 12427-12435.

25. Mikami M, Yamazaki M, Yui S. Kinetical analysis of tumor cell deathinducing mechanism by polymorphonuclear leukocyte-derived calprotectin: involvement of protein synthesis and generation of reactive oxygen species in target cells. Microbiol Immunol 1998; 42: 211-221.

26. Loomans HJ, Harn BL, Li Q, Phadnis SH, Sohnle PG. Histidine-based zincbinding sequences and the antimicrobial activity of calprotectin. J Infect Dis 1998; 177: 812-814.

27. McCabe MJ Jr, Jiang SA, Orrenius S. Chelation of intracellular zinc triggers apoptosis in mature thymocytes. Lab Invest 1993; 69: 101-110.

28. Chai F, Truong-Tran AQ, Ho LH, Zalewski PD. Regulation of caspase activation and apoptosis by cellular zinc fluxes and zinc deprivation: a review. Immunol Cell Biol 1999; 77: 272-278.

29. Nakatani T, Tawaramoto M, Kennedy DO, Kojima A, Matsui-Yuasa I. Apoptosis induced by chelation of intracellular zinc is associated with depletion of cellular reduced glutathione level in rat hepatocytes. Chem Biol Interact 2000; 15: 151-163.

30. Hyun HJ, Sohn J, Ahn Y-H, Shin H-C, Koh J-Y, Yoon YH. Depletion of intracellular zinc induces macromolecule synthesis- and caspasedependent apoptosis of cultured retinal cells. Brain Res 2000; 30: 39-48.

31. Pröpper C, Huang X, Roth J, Sorg C, Nacken W. Analysis of the MRP8 MRP14 protein-protein interaction by the two-hybrid system suggests a prominent role of the $\mathrm{C}$-terminal domain of $\mathrm{S} 100$ proteins in dimer formation. J Biol Chem 1999; 274: 183-188.

32. Brodersen DE, Nyborg J, Kjeldgaard M. Zinc-binding site of an $\mathbf{S 1 0 0}$ protein revealed. Two crystal structures of $\mathrm{Ca}^{2+}$-bound human psoriasin (S100A7) in the $\mathrm{Zn}^{2+}$-loaded and $\mathrm{Zn}^{2+}$-free states. Biochemistry 1999; 38 : 1695-1704

33. Mäler L, Potts BC, Chasing WJ. High resolution solution structure of apo calcyclin and structural variations in the $\$ 100$ family of calcium-binding proteins. J Biomol NMR 1999; 13: 233-247.

34. Randazzo A, Acklin C, Schafer BW, Heizmann CW, Chazin WJ. Structural insight into human $\mathrm{Zn}^{2+}$-bound S100A2 from NMR and homology modeling. Biochem Biophys Res Commun 2001; 288: 462-467.

35. Koike T, Kondo K, Makita T, Kajiyama K, Yoshida T, Morikawa M. Intracellular localization of migration inhibitory factor-related protein (MRP) and detection of cell surface MRP binding sites on human leukemia cell lines. J Biochem (Tokyo) 1998; 123: 1079-1087.

36. Ribeiro JM, Carson DA. $\mathrm{Ca}^{2+} / \mathrm{Mg}^{2+}$-dependent endonuclease from human spleen: purification, properties, and role in apoptosis. Biochemistry 1993; 32: 9129-9136.

37. Marini M, Frabetti F, Canaider S, Dini L, Falcieri E, Poirier G. Modulation of caspase- 3 activity by zinc ions and the cell redox state. Exp Cell Res 2001; 266: 323-332. 
38. Martin SJ, Mazdai G, Strain JJ, Cotter TG, Hannigan BM. Programmed cell death (apoptosis) in lymphoid and myeloid cell lines during zinc deficiency. Clin Exp Immunol 1991; 83: 338-343.

39. Versieck J, Cornelis R. Normal levels of trace elements in human blood plasma or serum. Anal Chim Acta 1980; 116: 217-254.

40. Cunnane SC. Zinc: Clinical and Biochemical Significance. Boca Raton, FL: CRC Press, 1988: 69.
41. Sohnle PG, Collins-Lech C, Wiessner JH. The zinc-reversible antimicrobial activity of neutrophil lysates and abscess fluid supernatants.J Infect Dis 1991; 164: 137-142.

Received 12 February 2002

Accepted 12 March 2002 


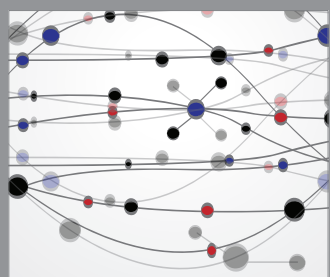

The Scientific World Journal
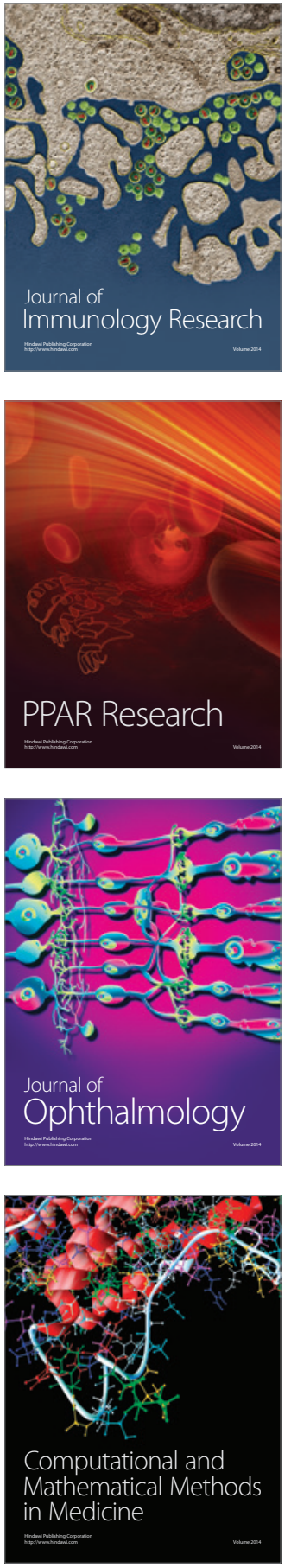

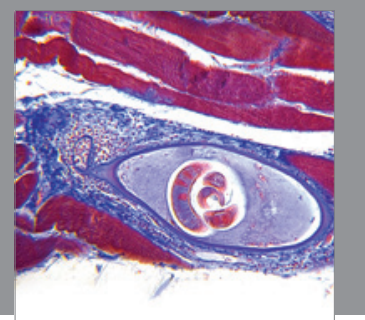

Gastroenterology

Research and Practice
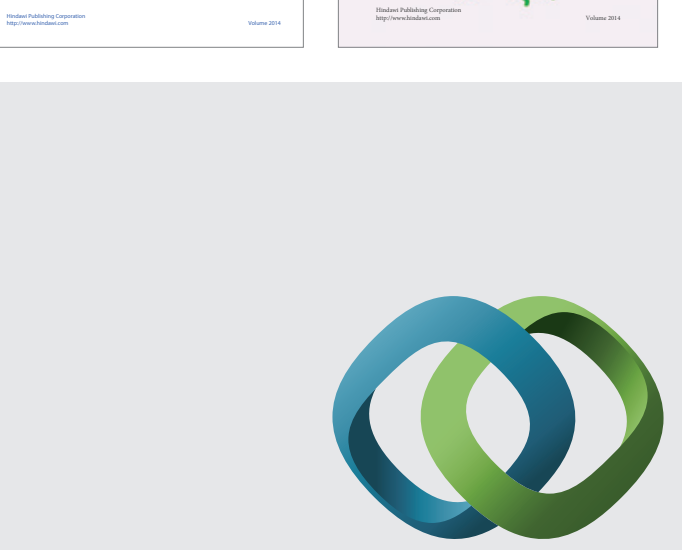

\section{Hindawi}

Submit your manuscripts at

http://www.hindawi.com
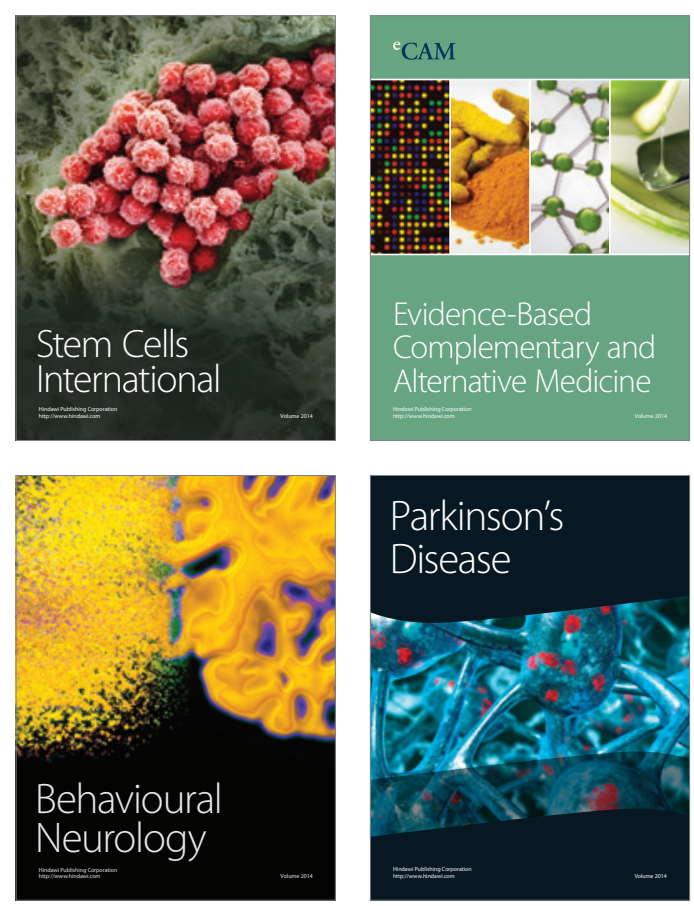

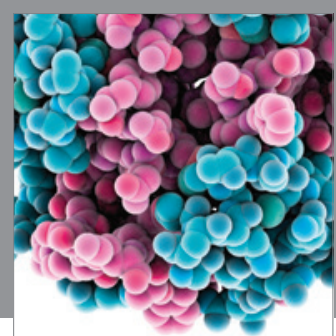

Journal of
Diabetes Research

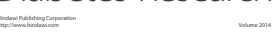

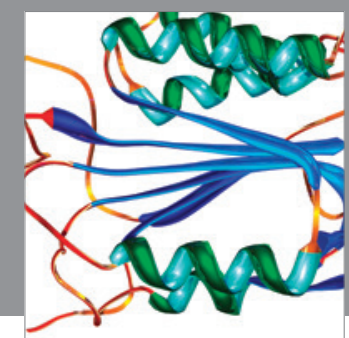

Disease Markers
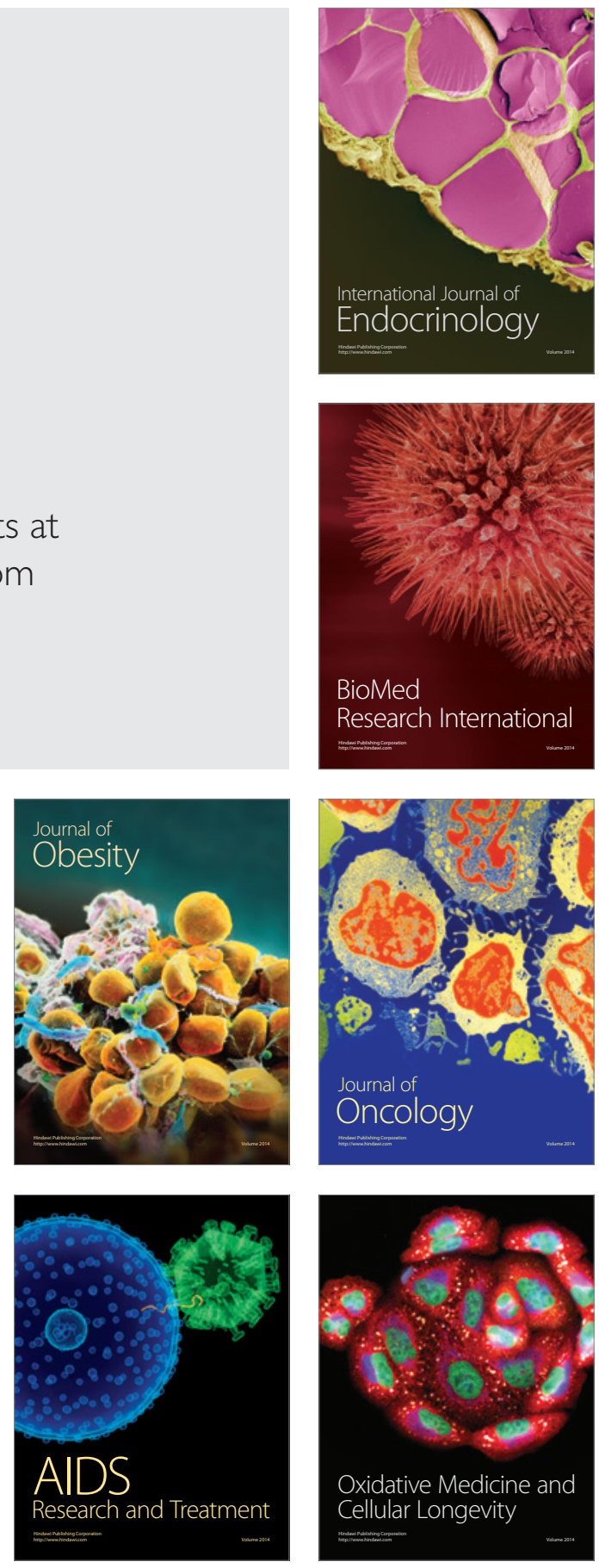